\title{
KEBIJAKAN ANGSURAN PAJAK PENGHASILAN WAJIB PAJAK ORANG PRIBADI PENGUSAHA TERTENTU: STUDI KASUS USAHA MIKRO DI INDONESIA
}

\author{
Fany Inasius \\ Accounting and Finance Department, Faculty of Economic and Communication, BINUS University \\ Jln. K. H. Syahdan No. 9, Palmerah, Jakarta Barat 11480 \\ marcel8844@yahoo.com
}

\begin{abstract}
The instalment of Income Tax for Individual Taxpayers of particular enterpreneur is determined at 0.75\% of the total circulation of business under section 25 Income Tax Act, 2008. The prepaid's payment of income tax implies the underpayment or overpayment of tax at the end of the tax year. If there is an overpayment of tax audits, it will be conducted according to the Law Number 28 of 2007 on the General Provisions of Taxation. This paper focuses on the discussion of income tax installments by individual taxpayer particular enterpreneur categorized as micro entrepreneurs. Based on the research conducted by the method of comparative research, descriptive and analytical documents, results show that the maximum limit of circulation to all types of businesses at the lowest rates and the type of agricultural businesses in the highest rates occur overpayment. It means the cost of taxation for individual taxpayers of particular entrepreneurs in micro business. This causes a particular burden for micro individual taxpayers of particular enterpreneur besides less aligned with the goal of the Income Tax Act change.
\end{abstract}

Keywords: SMEs, the latest Income Tax Act, the old Income Tax Act

\begin{abstract}
ABSTRAK
Angsuran Pajak Penghasilan (PPh) untuk Wajib Pajak Orang Pribadi (WPOP) Pengusaha tertentu ditetapkan sebesar 0,75\% dari total peredaran usaha berdasarkan pasal 25 Undang-Undang PPh tahun 2008 (UU PPh). Pembayaran PPh di muka berimplikasi pada kurang bayar atau lebih bayar pajak pada akhir tahun pajak. Jika terjadi lebih bayar, pemeriksaan pajak akan dilakukan sesuai Undang-Undang Nomor 28 tahun 2007 tentang Ketentuan Umum Perpajakan. Penulisan ini berfokus pada pembahasan angsuran PPh oleh WPOP pengusaha tertentu kategori usaha mikro. Penelitian dilakukan dengan metode penelitian komparatif, deskriptif, dan analisis dokumen. Hasil menunjukkan bahwa pada batas maksimal peredaran usaha mikro untuk semua jenis usaha pada tarif terendah maupun jenis usaha pertanian pada tarif tertinggi terjadi lebih bayar. Hal itu berarti cost of taxation bagi WPOP pengusaha tertentu usaha mikro. Hal ini menimbulkan beban bagi WPOP pengusaha tertentu mikro selain kurang selaras dengan tujuan perubahan UU PPh.
\end{abstract}

Kata kunci: WPOP pengusaha tertentu, usaha mikro, angsuran PPh 


\section{PENDAHULUAN}

Usaha Mikro Kecil Menengah (UMKM) memainkan peranan yang penting dan signifikan bagi pertumbuhan ekonomi di Indonesia. Ronald Waas, dalam uji ketaatan dan kelayakan calon Deputi Gubernur BI pada 5 Desember 2011 menyatakan bahwa jumlah Usaha Kecil Menengah (UKM) di Indonesia mencapai sekitar 52 juta UKM serta menyumbang 60\% dari PDB dan menampung 97 persen tenaga kerja pada 2011 sebagaimana dikutip dari Purnomo (2011). Bahkan di Asia Pasifik UKM masih menjadi sumber penting dari penciptaan lapangan kerja serta menyumbang lebih dari 70\% lapangan pekerjaan di China, Jepang, India, Indonesia, Taiwan dan Vietnam (ESCAP, 2009). Di Indonesia jumlah UMKM pada 2012 mencapai sekitar 56 juta UKM dengan kontribusi sekitar 60 persen terhadap PDB serta menampung sekitar 97 persen tenaga kerja (Kementerian Koperasi dan UMK, 2012).

Peraturan pemerintah khususnya perpajakan merupakan salah satu fokus utama sektor bisnis di seluruh dunia. Pengalaman internasional menunjukkan bahwa beban regulasi tampaknya jatuh tidak proporsional pada UKM (Pope \& Abdul-Jabbar, 2008). Dunia usaha dengan ukuran baik besar maupun kecil wajib memtuhi peraturan yang berlaku termasuk peraturan di bidang perpajakan.

Secara peraturan perpajakan di Indonesia maka UMKM dapat berupa Badan maupun Wajib Pajak Orang Pribadi (WPOP). Adapun WPOP yang melakukan usaha sebagian besar menggunakan norma sehingga dapat dikatakan dikatakan bahwa WPOP tersebut merupakan WPOP UKM. Karena UKM memainkan peranan yang signifikan, tujuan penelitian ini adalah membahas penerapan kebijakan Peraturan Dirjen Pajak nomor 32/PJ/2010 tentang pelaksanaan PPh pasal 25 bagi WPOP pengusaha tertentu sebagai pelaksana pasal 25 ayat (7) UU Nomor 36 Tahun 2008 tentang Pajak Penghasilan (UU PPh tahun 2008) di Indonesia. Pembahasan ini untuk mengetahui pelaksanaan PER32/PJ/2010 memberi kemudahan atau menimbulkan tax compliance cost bagi WPOP UKM. Adapun fokus pada pembahasan ini pada tax compliance dan beban administrasi PPh pengusaha orang pribadi (OP) yang peredarannya di bawah 300 juta rupiah per tahun.

Pembahasan bagi UKM dimulai dengan pembahasan peraturan perpajakan tentang PPh WPOP Pengusaha tertentu sebagaimana diatur dalam UU PPh tahun 2008. Pembahasan berikut tentang implikasi peraturan tentang PPh WPOP Pengusaha Tertentu terhadap beban tax compliance dan beban administrasi. Bagian terakhir membuat simpulan atas studi ini.

\section{Analisis Pustaka}

Sesuai dengan UU PPh tahun 2008, maka subjek pajak penghasilan dapat berupa badan maupun Orang Pribadi (OP). Adapun tarif atas kedua subjek pajak tersebut diatur dalam pasal 17 UU PPh tahun 2008. Untuk Wajib Pajak Orang Pribadi dibagi menjadi empat lapisan, yaitu: untuk penghasilan kena pajak sampai dengan 50 juta rupiah dengan tarif 5 persen, penghasilan kena pajak antara 50 juta rupiah sampai 250 juta rupiah dengan tarif 15 persen, penghasilan antara 250 juta sampai 500 juta dengan tarif 25\%, terakhir untuk penghasilan kena pajak di atas 500 juta rupiah dengan tarif 30 persen.

Untuk memberi kemudahan pelaksanaan perpajakan maka bagi WPOP yang peredaran usaha di bawah 4.8 milyar rupiah diperbolehkan menggunakan norma penghitungan penghasilan neto dalam menghitung jumlah pajak tahunan yang terutang dengan syarat memberitahukan kepada Direktur Jenderal Pajak (DJP) dalam jangka waktu tidak melebihi 3 bulan pertama tahun pajak tersebut (UU PPh Tahun 2008). Dengan demikian dapat disimpulkan bahwa WPOP harus menggunakan pembukuan dalam rangka penghitungan pajak tahunan kecuali peredaran usaha WPOP tersebut di bawah 4.8 milyar rupiah dan melaporkan ke DJP sebelum akhir Maret tahun pajak tersebut. 
Secara universal tidak ada definisi yang disepakati tentang UKM sehingga berbagai definisi diterapkan di berbagai negara antara lain meliputi jumlah karyawan atau total modal yang disetor. OECD (2009) memberikan karakteristik tentang UKM sebagai usaha yang bukan merupakan anak perusahaan, independent, dengan jumlah pegawai kurang dari jumlah tertentu dimana jumlah tersebut bervariasi antarnegara. Lebih lanjut Abe et al (2012) beragumentasi bahwa pengertian UKM bukan hanya beragam antarnegara; bahkan dalam sebuah negara tergantung pada sektor bisnis yang bersangkutan, misalnya sektor pertanian, sumber daya alam, industri manufaktur, jasa, dan usaha retail.

Di Indonesia UMKM diatur dalam UU nomor 20 tahun 2008 yang mendefinisikan UKM dalam tiga kriteria yaitu usaha mikro, kecil, dan menengah. Sesuai UU Nomor 20 tahun 2008, usaha mikro adalah usaha yang memiliki hasil penjualan tahunan sampai dengan Rp300.000.000; sementara usaha kecil adalah usaha yang penjualan tahunan antara Rp300.000.000 sampai Rp2.500.000.000. Adapun usaha menengah adalah usaha yang memiliki jumlah penjualan tahunan antara Rp2.500.000.000 sampai Rp50.000.000.000.

UU PPh nomor 36 tahun 2008 telah memberi ruang kemudahan bagi WPOP dengan meningkatkan batas peredaran bruto untuk dapat menggunakan norma menjadi 4.8 miliar per tahun. Jika dikaitkan dengan batasan UMKM sesuai UU nomor 20 tahun 2008, peraturan tentang penggunaan norma bagi WPOP ditujukan untuk lebih memberikan kemudahan bagi OP kategori UKM. Dengan demikian dapat disimpulkan bahwa WPOP identik dengan usaha UMKM.

Sesuai dengan pasal 25 ayat (7) UU PPh tahun 2008 sebagaimana diatur lebih lanjut dalam Peraturan Menteri Keuangan Nomor 208/PMK.03/2009, maka pengertian WPOP pengusaha tertentu adalah WPOP yang melakukan kegiatan usaha sebagai pedagang pengecer adalah yang mempunyai tempat usaha satu lebih. Selanjutnya berdasarkan PER-32/PJ/2010, maka pedagang pengecer OP adalah yang melakukan usaha baik secara grosir maupun eceran dan atau penyerahan jasa dengan angsuran sebesar $0.75 \%$ dari jumlah peredaran bruto yang angsuran tersebut merupakan kredit pajak atas PPh untuk tahun pajak yang bersangkutan. Berdasarkan definisi, dapat disimpulkan WPOP termasuk kategori WPOP pengusaha tertentu jika WPOP memiliki usaha di bidang retail baik satu atau lebih tempat usaha. Selanjutnya jika WPOP termasuk kategori pengusaha tertentu, mereka memiliki kewajiban setiap bulan untuk membayar angsuran PPh pasal 25 sebesar $0.75 \%$ dari total peredaran bruto.

Konsekuensi pembayaran angsuran $\mathrm{PPh}$ terhadap penghitungan pajak akhir tahun adalah terjadi kelebihan atau kekurangan bayar pajak tahunan. Jika terjadi kekurangan pembayaran, sebagai WPOP wajib melunasi jumlah pajak terutang paling lambat pada akhir bulan ketiga tahun berikut sesuai UU PPh tahun 2008. Namun jika terjadi kelebihan bayar sesuai pasal 17 UU Nomor 28 tahun 2007 tentang Ketentuan Umum Perpajakan (UU KUP), Dirjen pajak setelah melakukan pemeriksaan menerbitkan Surat Ketetapan Lebih Bayar jika jumlah pajak yang dibayar lebih besar daripada pajak terutang. Dengan demikian dapat disimpulkan bahwa jika terjadi lebih bayar Surat Pemberitahuan tahunan (SPT tahunan) WPOP, WPOP tersebut wajib diperiksa oleh Direktorat Jenderal Pajak.

Sesuai dengan pasal 1 UU KUP, maka Pemeriksaan adalah serangkaian kegiatan menghimpun dan mengolah data, keterangan, dan/atau bukti yang dilaksanakan secara objektif dan profesional berdasarkan suatu standar pemeriksaan untuk menguji kepatuhan pemenuhan kewajiban perpajakan dan/atau untuk tujuan lain dalam rangka melaksanakan ketentuan peraturan perundang-undangan perpajakan. Berdasarkan definisi di atas dapat disimpulkan bahwa bagi OP yang diperiksa wajib menyediakan data yang dibutuhkan serta waktu untuk mengkomunikasikan data yang telah dilaporkaan. Hal ini merupakan beban bagi WPOP Pengusaha tertentu karena harus comply terhadap peraturan yang tidak mudah bagi WPOP. 
Chittendend et al (2003) dalam meninjau tax compliance WP UKM di USA, UK, Australia, dan New Zealand mencatat ketidakmampuan WP UKM dibandingkan perusahaan besar dalam berhubungan dengan peraturan pajak yang rumit. Adapun tax complexity dapat diukur dengan baik melalui tax compliance costs (James et al. 1998; Pope, 1993b; Slemrod, 1992). Selanjutnya tax compliance cost menurut Pope et al (2008) dan Sandford et.al (1989) terdiri dari dari tiga komponen utama yaitu monetary costs, time costs dan psychological costs. Monetary cost meliputi waktu yang digunakan untuk biaya professional, alat tulis kantor buku petunjuk dan lain-lain biya tidak terduga terkait perpajakan. Time costs terkait dengan pencatatan, pelaporan Surat Pemberitahuan masa maupun tahunan dan waktu yang dibutuhkan dalam berhubungan dengan kantor pajak. Psychological costs meliputi kecemasan dalam menangani permasalahan pajak yang kompleks.

Tax compliance didefinisikan oleh Kirchler (2007) secara sederhana sebagai istilah yang paling netral untuk menggambarkan kesediaan pembayar pajak untuk membayar pajak. Definisi yang lebih luas diungkapkan oleh Song dan Yarbrough (1978) bahwa tax compliance merupakan kemampuan dan keinginan pembayar pajak untuk taat hukum pajak yang ditetapkan oleh etika, hukum dan factor situasional lain pada waktu dan tempat tertentu. Tax compliance juga didefinisikan sebagai pelaporan semua penghasilan dan pembayaran pajak dengan meemenuhi ketentuan hukum, peraturan dan keputusan pengadilan (Jackson \& Milliron, 1986). Maka berdasarkan definisi tersebut dapat disimpulkan bahwa tax compliance merupakan kesediaan pembayar pajak untuk mematuhi peraturan pajak, melaporkan penghasilan, mengklaim pengurangan dengan benar dan membayar keseluruhan pajak tepat waktu.

\section{METODE}

Metode yang digunakan dalam pelaksanaan penelitian adalah metode penelitian komparatif, deskriptif dan analisa dokumen. Penelitian komparatif dilakukan dengan melakukan penyelidikan dan pemahaman terhadap peraturan perpajakan yang telah berlaku dikaitkan dengan reaksi subyek penelitian dengan pengumpulan data yang berasal dari peraturan perpajakan. Adapun penelitian deskriptif dilakukan dengan melakukan penilaian atas perturan yang telah ada. Berdasarkan analisa literatur dan observasi terhadap data-data yang diperoleh dibuat perbandingan yang dapat memberikan gambaran untuk menjawab pertanyaan mengenai tujuan penelitian.

\section{HASIL DAN PEMBAHASAN}

\section{Pajak Penghasilan WPOP Pengusaha Tertentu}

Sejak 2007 hingga 2010 telah terjadi reformasi atas tiga Undang-Undang (UU) Pajak di Indonesia. Perubahan atas UU Pajak ini dimulai dengan UU Nomor 28 tahun 2007 tentang Ketentuan Umum Perpajakan yang mulai berlaku sejak 1 Januari tahun 2008, disusul dengan UU Nomor 36 tahun 2008 tentang UU Pajak Penghasilan yang mulai berlaku 1 Januari 2009 dan diakhiri dengan UU Nomor 42 tahun 2009 yang mulai berlaku sejak 1 Mei 2010.

Pajak Penghasilan sebagai komponen terbesar dalam penenerimaan pajak pusat telah mengalami beberapa kali perubahan dengan perubahan terakhir adalah UU Nomor 17 tahun 2000. Pertimbangan pesatnya perkembangan social ekonomi sebagai hasil pembangunan nasional dan globalisasi serta reformasi di berbagai bidang maka penyempurnaan UU PPh bertujuan untuk antara lain lebih meningkatkan keadilan pengenaan pajak, lebih memberikan kesederhanaan administrasi pajak, lebih memberrikan kemudahan dan kepastian hukum kepada Wajib Pajak. Selanjutnya 
berlandaskan pada tujuan penyempurnaan PPh maka perubahan UU PPh tahun 2000 menjadi UU PPh tahun 2008 meliputi antara lain meningkatkan keadilan pengenaan pajak, mengedepankan prinsip keadilan dan netralitas dalam penetapan tarif serta memberikan dorongan bagi berkembangnya usahausaha kecil.

Untuk memberikan kemudahan bagi WPOP maka WPOP yang peredaran usaha di bawah 4.8 milyar rupiah diperbolehkan menggunakan norma sesuai pasal 14 UU PPh. Dengan penggunaan norma maka WPOP akan lebih mudah dalam penghitungan pajak. Untuk ilustrasi, berikut contoh jika seorang WPOP yang memiliki peredaran usaha setahun sebesar 500 juta rupiah sehingga boleh menggunakan norma. Untuk penghitungan pajak terutang WPOP tersebut menggunakan Norma Penghitungan Penghasilan Neto dengan tarif norma sebesar 10 persen. Maka berdasarkan contoh ini Penghasilan kena pajak WPOP tersebut adalah 50 juta rupiah (10\% X Rp 500 juta) dengan utang pajak adalah dua juta lima ratus ribu rupiah (5\%X Rp50 juta).

Selanjutnya untuk mendapatkan gambaran tentang jumlah WPOP berikut adalah data WPOP sejak tahun 2008 hingga 2012 berdasarkan data yang diperoleh dari Humas DJP yang meliputi WPOP pengguna norma dan WPOP yang menyelenggarakan pembukuan sebagaimana ditampilkan dalam Tablel 1.

Tabel 1 Jumlah WPOP yang Melakukan Usaha

\begin{tabular}{lrrrrr} 
& \multicolumn{1}{c}{$\mathbf{2 0 0 8}$} & $\mathbf{2 0 0 9}$ & $\mathbf{2 0 1 0}$ & \multicolumn{1}{c}{$\mathbf{2 0 1 1}$} & \multicolumn{1}{c}{$\mathbf{2 0 1 2}$} \\
\hline Norma & $3,060,113$ & $4,095,391$ & $4,294,224$ & $4,328,584$ & $4,420,272$ \\
Pembukuan & 90,853 & 97,911 & 100,062 & 101,107 & 101,123 \\
Jumlah WPOP Usaha & $3,150,966$ & $4,193,302$ & $4,394,286$ & $4,429,691$ & $4,521,395$ \\
\hline
\end{tabular}

Berdasarkan data dapat diketahui bahwa jumlah WPOP pengguna norma sekitar 98\% dari jumlah WPOP yang melakukan usaha. Hal ini berarti bahwa mayoritas WPOP yang melakukan usaha adalah WPOP yang peredaran usaha di bawah 4.8 milyar rupiah atau termasuk dalam kategori UMKM. Di samping itu dari dua persen WPOP yang menyelenggarakan pembukuan bisa terdapat kemungkinan memiliki kategori sebagai UMKM. Dengan demikian dapat disimpulkan bahwa mayoritas WPOP (lebih dari 98 persen) merupakan UMKM.

Untuk mendapatkan gambaran tentang jumlah WPOP pengusah tertentu berikut data WPOP yang menggunkan norma dan WPOP pengusaha tertentu seperti dalam Tabel 2 berikut.

Tabel 2 Jumlah WPOP Norma dan Pengusaha Tertentu

\begin{tabular}{lllllc}
\hline & $\mathbf{2 0 0 8}$ & $\mathbf{2 0 0 9}$ & $\mathbf{2 0 1 0}$ & $\mathbf{2 0 1 1}$ & $\mathbf{2 0 1 2}$ \\
\hline WPOP Norma & $3,060,113$ & $4,095,391$ & $4,294,224$ & $4,328,584$ & $4,420,272$ \\
WPOP Pengusaha Tertentu & $2,319,437$ & $3,026,175$ & $3,528,613$ & $3,930,315$ & $4,392,067$ \\
\hline
\end{tabular}

Berdasarkan data pada Tabel 2 dapat diketahui bahwa jumlah WPOP Pengusaha tertentu adalah 74 persen dari total WPOP yang melakukan usaha pada tahun 2008 dan mecapai 97 persen di tahun 2012. Dengan demikian total WPOP Pengusaha tertentu merupakan mayoritas dari total WPOP yang melakukan usaha sehingga dapat disimpulkan bahwa mayoritas WPOP pengusaha tertentu termasuk dalam kategori UKM yaitu peredaran usaha di bawah 4.8 milyar rupiah.

Dalam pelaksanaan pemenuhan kewajiban pajak penghasilan (PPh) maka WPOP Pengusaha tertentu wajib membayar angsuran PPh bulanan sejumlah 0.75 persen dari total peredaran usaha. Adapun pembayaran angsuran $\mathrm{PPh}$ bulanan tersebut merupakan uang muka $\mathrm{PPh}$ yang dapat diperhitungkan dalam penghitungan pajak tahunan. 


\section{Implikasi PPh WPOP Pengusaha Tertentu}

Penghitungan PPh WPOP akhir tahun untuk WPOP Pengusaha tertentu diasumsikan menggunakan norma karena lebih dari 97 persen jumlah WPOP yang melakukan usaha sejak 2008 sampai 2012 adalah WPOP pengguna Norma. Faktor yang memengaruhi pemilihan Norma karena kemudahan dalam segi administrasi walaupun tidak memenuhi rasa keadilan karena tidak adanya pengakuan terhadap kerugian (Sari, 2012). Selanjutnya untuk gambaran tentang tarif Norma Pedagang Eceran Tabel 3 berikut menampilkan daftar tarif norma yang dimodifikasi dengan penyebutan tarif tertinggi untuk ibu kota propinsi dan tarif terendah untuk selain ibu kota propinsi berdasarkan Lampiran I Keputusan Dirjen Pajak Nomor: KEP-536/PJ./2000 tentang Norma Perhitungan WP Perseorangan:

Tabel 3 Tarif Pedagang Eceran

\begin{tabular}{lcc}
\hline \multirow{2}{*}{ Jenis Usaha } & \multicolumn{2}{c}{ Tarif } \\
\cline { 2 - 3 } & Tertinggi & Terendah \\
\hline Perdagangan Besar & 30 & \\
Hasil Pertanian & 20 & 15 \\
Peternakan \& Perikanan & 25 & 20 \\
Kehutanan & 25 & 20 \\
Bahan makanan\& minuman & 25 & 20 \\
Tekstil \& Pakaian & 25 & 20 \\
Kertas \& Alat Tulis Kantor & 25 & 20 \\
Industri Kimia \& Farmasi & 5 & 3 \\
BBM & 25 & 20 \\
Bahan bangunan & 25 & 20 \\
Mesin \& Onderdil & 25 & 20 \\
Elektronik & & \\
Perdagangan Eceran & 30 & 20 \\
Eceran Minimarket & 20 & 15 \\
Eceran: Pertanian Peternakan & 25 & 20 \\
Eceran: Bahan makanan, minuman & 30 & 20 \\
Eceran Tekstil & 30 & 20 \\
Eceran Perabot rumah tangga & 30 & 20 \\
Eceran Elektronik & 30 & 20 \\
Eceran industri Kimia & 30 & 20 \\
Eceran Bahan bangunan & 25 & 20 \\
Eceran Hasil Penggalian & 30 & 20 \\
Eceran hasil industri Pengolahan & 30 & 20 \\
Eceran Kertas \& Alat Tulis & 30 & 20 \\
Eceran Mesin \& Onderdil & & \\
\hline
\end{tabular}

Berdasarkan Tabel 3 terlihat bahwa tarif norma dimulai dari 3 persen hingga 30 persen. Namun sebagian besar usaha dikenakan tarif tertinggi 30 persen dan terendah pada 20 persen.

Mengingat peraturan Dirjen Pajak tentang norma tidak memberi batasan tentang perdagangan besar dan eceran untuk pengguna norma, maka pembatasan dalam studi ini berdasarkan UU Nomor 20 tahun 2008 tentang pengusaha mikro. Adapun batasan untuk pengusaha mikro adalah pengusaha yang peredaran usaha maksimal 300 juta rupiah setahun. Selanjutnya metode penghitungan untuk menentukan pajak terutang adalah sebagai berikut:

Asumsi jumlah peredaran usaha $=300$ juta rupiah. Penghasilan tidak kena pajak $(\mathrm{PTKP})$ diasumsikan WPOP tidak kawin dan tanpa tanggungan sesuai Peraturan Menteri Keuangan Nomor 32 tahun 2012 yang mulai berlaku 1 Januari 2013 sebesar Rp24,300,000 per tahun. Jumlah Pajak terutang 
berdasarkan angsuran WPOP Pengusaha tertentu sesuai pasal 25 ayat (7) UU PPh tahun 2008 adalah $0.75 \% \mathrm{X}$ total peredaran usaha. Jumlah Penghasilan bruto bagi pengguna norma $=$ tarif norma $\mathrm{X}$ Jumlah peredaran bruto. Jumlah Penghasilan kena pajak = Jumlah penghasilan bruto-PTKP. Pajak terutang sesuai tarif pajak dalam pasal 17 UU PPh tahun 2008 yakni: Penghasilan sampai 50 juta rupiah adalah $5 \%$ dan antara 50 juta sampai 250 juta rupiah $=15 \%$.

Berdasarkan asumsi peredaran usaha adalah batas maksimal bagi usaha mikro sebesar Rp300 juta, maka Tabel 4, 5,6 dan 7 berturut turut menampilkan pajak terutang bagi masing-masing jenis usaha eceran untuk tarif tertinggi dan terendah serta implikasi angsuran PPh WPOP terhadap kurang atau lebih bayar akhir tahun PPh WPOP tertentu.

Tabel 4 Pajak Terutang pada Tarif Tertinggi

\begin{tabular}{lccccc}
\hline & $\begin{array}{c}\text { Tarif } \\
\text { Norma }\end{array}$ & $\begin{array}{c}\text { Penghasilan } \\
\text { Bruto }\end{array}$ & PTKP & $\begin{array}{c}\text { Ph. Kena } \\
\text { Pajak }\end{array}$ & $\begin{array}{c}\text { Pajak } \\
\text { Terutang }\end{array}$ \\
\hline Eceran Minimarket & 30 & $90,000,000$ & $24,300,000$ & $65,700,000$ & $4,855,000$ \\
Eceran: Pertanian Peternakan & 20 & $60,000,000$ & $24,300,000$ & $35,700,000$ & $1,785,000$ \\
Eceran: Bahan makanan, minuman & 25 & $75,000,000$ & $24,300,000$ & $50,700,000$ & $2,605,000$ \\
Eceran Tekstil & 30 & $90,000,000$ & $24,300,000$ & $65,700,000$ & $4,855,000$ \\
Eceran Perabot rumah tangga & 30 & $90,000,000$ & $24,300,000$ & $65,700,000$ & $4,855,000$ \\
Eceran Elektronik & 30 & $90,000,000$ & $24,300,000$ & $65,700,000$ & $4,855,000$ \\
Eceran industri Kimia & 30 & $90,000,000$ & $24,300,000$ & $65,700,000$ & $4,855,000$ \\
Eceran Bahan bangunan & 30 & $90,000,000$ & $24,300,000$ & $65,700,000$ & $4,855,000$ \\
Eceran Hasil Penggalian & 25 & $75,000,000$ & $24,300,000$ & $50,700,000$ & $2,605,000$ \\
Eceran hasil industri Pengolahan & 30 & $90,000,000$ & $24,300,000$ & $65,700,000$ & $4,855,000$ \\
Eceran Kertas \& Alat Tulis & 30 & $90,000,000$ & $24,300,000$ & $65,700,000$ & $4,855,000$ \\
Eceran Mesin \& Onderdil & 30 & $90,000,000$ & $24,300,000$ & $65,700,000$ & $4,855,000$ \\
\hline
\end{tabular}

Tabel 5 Pajak Terutang pada Tarif Terendah

\begin{tabular}{lccccc}
\hline & $\begin{array}{c}\text { Tarif } \\
\text { Norma (\%) }\end{array}$ & $\begin{array}{c}\text { Penghasilan } \\
\text { Bruto }\end{array}$ & PTKP & $\begin{array}{c}\text { Ph. Kena } \\
\text { Pajak }\end{array}$ & $\begin{array}{c}\text { Pajak } \\
\text { Terutang }\end{array}$ \\
\hline Eceran Minimarket & 20 & $60,000,000$ & $24,300,000$ & $35,700,000$ & $1,785,000$ \\
Eceran: Pertanian Peternakan & 15 & $45,000,000$ & $24,300,000$ & $20,700,000$ & $1,035,000$ \\
Eceran: Bahan makanan, minuman & 20 & $60,000,000$ & $24,300,000$ & $35,700,000$ & $1,785,000$ \\
Eceran Tekstil & 20 & $60,000,000$ & $24,300,000$ & $35,700,000$ & $1,785,000$ \\
Eceran Perabot rumah tangga & 20 & $60,000,000$ & $24,300,000$ & $35,700,000$ & $1,785,000$ \\
Eceran Elektronik & 20 & $60,000,000$ & $24,300,000$ & $35,700,000$ & $1,785,000$ \\
Eceran industri Kimia & 20 & $60,000,000$ & $24,300,000$ & $35,700,000$ & $1,785,000$ \\
Eceran Bahan bangunan & 20 & $60,000,000$ & $24,300,000$ & $35,700,000$ & $1,785,000$ \\
Eceran Hasil Penggalian & 20 & $60,000,000$ & $24,300,000$ & $35,700,000$ & $1,785,000$ \\
Eceran hasil industri Pengolahan & 20 & $60,000,000$ & $24,300,000$ & $35,700,000$ & $1,785,000$ \\
Eceran Kertas \& Alat Tulis & 20 & $60,000,000$ & $24,300,000$ & $35,700,000$ & $1,785,000$ \\
Eceran Mesin \& Onderdil & 20 & $60,000,000$ & $24,300,000$ & $35,700,000$ & $1,785,000$ \\
\hline
\end{tabular}

Tabel 6 Jumlah Kurang (Lebih) Bayar pada Tarif Tertinggi

\begin{tabular}{lrrr}
\multicolumn{1}{c}{ Jenis Usaha } & $\begin{array}{c}\text { Angsuran } \\
\text { Pajak Tahunan }\end{array}$ & $\begin{array}{c}\text { Jumlah } \\
\text { Pajak Terutang }\end{array}$ & $\begin{array}{c}\text { Kurang (Lebih) } \\
\text { Bayar }\end{array}$ \\
\hline Eceran Minimarket & $2,250,000$ & $4,855,000$ & $2,605,000$ \\
Eceran: Pertanian Peternakan & $2,250,000$ & $1,785,000$ & $(465,000)$ \\
Eceran: Bahan makanan, minuman & $2,250,000$ & $2,605,000$ & 355,000 \\
Eceran Tekstil & $2,250,000$ & $4,855,000$ & $2,605,000$ \\
Eceran Perabot rumah tangga & $2,250,000$ & $4,855,000$ & $2,605,000$ \\
Eceran Elektronik & $2,250,000$ & $4,855,000$ & $2,605,000$ \\
\hline
\end{tabular}




\begin{tabular}{lllr}
\hline Eceran industri Kimia & $2,250,000$ & $4,855,000$ & $2,605,000$ \\
Eceran Bahan bangunan & $2,250,000$ & $4,855,000$ & $2,605,000$ \\
Eceran Hasil Penggalian & $2,250,000$ & $2,605,000$ & 355,000 \\
Eceran hasil industri Pengolahan & $2,250,000$ & $4,855,000$ & $2,605,000$ \\
Eceran Kertas \& Alat Tulis & $2,250,000$ & $4,855,000$ & $2,605,000$ \\
Eceran Mesin \& Onderdil & $2,250,000$ & $4,855,000$ & $2,605,000$ \\
\hline
\end{tabular}

Tabel 7 Jumlah Kurang (Lebih) Bayar pada Tarif Terendah

\begin{tabular}{lrrr}
\hline \multicolumn{1}{c}{ Jenis Usaha } & $\begin{array}{c}\text { Angsuran Pajak } \\
\text { Tahunan }\end{array}$ & $\begin{array}{c}\text { Jumlah } \\
\text { Pajak Terutang }\end{array}$ & $\begin{array}{c}\text { Kurang (Lebih) } \\
\text { bayar }\end{array}$ \\
\hline Eceran Minimarket & $2,250,000$ & $1,785,000$ & $(465,000)$ \\
Eceran: Pertanian Peternakan & $2,250,000$ & $1,035,000$ & $(1,215,000)$ \\
Eceran: Bahan makanan, minuman & $2,250,000$ & $1,785,000$ & $(465,000)$ \\
Eceran Tekstil & $2,250,000$ & $1,785,000$ & $(465,000)$ \\
Eceran Perabot rumah tangga & $2,250,000$ & $1,785,000$ & $(465,000)$ \\
Eceran Elektronik & $2,250,000$ & $1,785,000$ & $(465,000)$ \\
Eceran industri Kimia & $2,250,000$ & $1,785,000$ & $(465,000)$ \\
Eceran Bahan bangunan & $2,250,000$ & $1,785,000$ & $(465,000)$ \\
Eceran Hasil Penggalian & $2,250,000$ & $1,785,000$ & $(465,000)$ \\
Eceran hasil industri Pengolahan & $2,250,000$ & $1,785,000$ & $(465,000)$ \\
Eceran Kertas \& Alat Tulis & $2,250,000$ & $1,785,000$ & $(465,000)$ \\
Eceran Mesin \& Onderdil & $2,250,000$ & $1,785,000$ & $(465,000)$ \\
\hline
\end{tabular}

Berdasarkan hasil penghitungan yang ditampilkan dalam Tabel 4 dan 5 serta Tabel 6 dan 7 dapat disimpulkan bahwa pada tarif tertinggi untuk jenis pedagang eceran peternakan terjadi lebih bayar jika angsuran PPh berdasarkan angsuran WPOP Pengusaha tertentu. Selanjutnya pada tarif terendah terjadi lebih bayar untuk semua jenis usaha.

Sebagaimana diatur dalam pasal 25 UU PPh bahwa WP baik OP maupun Badan memiliki kewajiban mengangsur PPh secara bulanan dan melaporkan pajak tahunan tersebut paling lambat 3 bulan setelah akhir tahun atau tanggal 31 Maret tahun berikut bagi WPOP dengan membayar kekurangan bayar PPh terutang sebelum melaporkan Pajak tahunan tersebut. Sebaliknya jika terjadi lebih bayar, WPOP dapat mengajukan permohonan restitusi untuk pengembalian kelebihan pajak tersebut. Namun sebelum dilakukan pengembalian kelebihan PPh tersebut, DJP wajib melakukan pemeriksaan untuk mengeluarkan ketetapan atas kelebihan bayar tersebut.

Pemeriksaan pajak bagi WP berarti kewajiban untuk mengumpulkan dokumen dan menjelaskan argumen yang mendukung kepada petugas pajak. Hal ini tidak mudah khususnya bagi WPOP pengusaha tertentu kecil mengingat dokumentasi data membutuhkan pengetahuan tentang perpajakan yang selain kompleks juga menyita waktu. Bagi WPOP di Indonesia restitusi berati monetary costs yaitu biaya yang dikeluarkan untuk mempelajari peraturan terkait dengan pemeriksaan pajak atau membayar konsultan pajak. Terkait dengan pemeriksaan, maka WP wajib menyediakan waktu untuk penyajian data laporan pajak. Selain itu WPOP harus siap menjelaskan data yang ada sesuai ketentuan perpajakan. Untuk hal tersebut WP memerlukan mental yang memadai terkait kekhawatiran karena kekurangpahaman terhadap peraturan pajak yang berlaku yang dapat diasosiasikan dengan phiysicological costs. Dengan demikian dapat disimpulkan bagi WPOP pengusaha tertentu usaha mikro kelebihan bayar menimbulkan tax compliance costs yang berarti beban administrasi, waktu maupun psikologi bagi WPOP. Dengan pertimbangan pada dorongan bagi berkembangnya usaha-usaha kecil maka pengenaan tarif angsuran bagi WPOP pengusaha tertentu menjadi kurang selaras dengan pokok peubahan UU PPh tahun 2008. 


\section{SIMPULAN}

Studi menunjukkan bahwa jumlah UMKM memainkan peranan yang signifikan bagi perekonomian Indonesia yakni berkontribusi sekitar 60 persen terhadap GDP serta menampung 97 persen tenaga kerja Indonesia dengan sekitar 97 persen WPOP Pengusaha Tertentu adalah adalah pengguna norma. Berdasarkan studi, dapat disimpulkan bahwa pengenaan tarif $0,75 \%$ dari total peredaran usaha, sebagai angsuran $\mathrm{PPh}$ bagi WPOP pengguna norma dengan jumlah peredaran usaha sebesar 300 juta rupiah yang merupakan batasan maksimal usaha mikro, mengakibatkan kelebihan bayar pada semua jenis usaha tarif rendah serta lebih bayar pada usaha perdagangan hasil pertanian dengan tarif tertinggi. Dengan demikian, pada peredaran usaha di bawah 300 juta rupiah akan makin bertambah jenis usaha yang akan mengalami lebih bayar untuk tarif tertinggi. Mengingat lebih bayar berarti timbulnya cost of tax compliance bagi WPOP pengusaha tertentu kategori usaha mikro, maka pengenaan tarif ini menjadi tidak sejalan dengan tujuan perubahan UU PPh tahun 2008 yang antara lain mendorong usaha kecil sebagaimana dalam penjelasan UU PPh tahun 2008. Pengenaan tarif bagi PPh WPOP pengusaha tertentu sesuai pasal 25 ayat (7) sebaiknya dievaluasi. Hal itu dilakukan dengan membuat batasan jumlah peredaran usaha minimal bagi pengguna norma yang dapat dikenakan tarif 0,75\%. Dengan begitu, terjadinya kelebihan bayar bagi WPOP usaha mikro dapat dihindari.

Keterbatasan studi ini lebih memfokuskan pada WPOP pengguna norma sesuai pasal 25 ayat (7) UU PPh. Pembahasan atas WPOP yang menyelenggarakan pembukuan, yang melaluinya tingkat keuntungan berbeda dengan pengguna norma, diperlukan untuk memberikan gambaran yang lebih lengkap tentang PPh atas WPOP pengusaha tertentu.

\section{DAFTAR PUSTAKA}

Abe, M., Troilo, M., Juneja, J. S., \& Narain, S. (2012). Policy Guide Book for SME Development in Asia and the Pacific. Bangkok: United Nations Publication. http://www.unescap.org/sites/default/files/0\%20-\%20Full\%20Report_7.pdf

Chittenden, F., Kauser, S., \& Poutziouris, P. (2003), Tax regulation and small Business in the USA, UK, Australia and New Zealand. International Small Business Journal, 21(1), 93-115.

ESCAP. (2009). Globalization of production and the competitiveness of Small and Mediumsized Enterprises in Asia and the Pacific: trends and prospects. Studies in Trade and Investment, 65. RePEc:unt:ecbook:tipub2540.

Jackson, B. R., \& Milliron, V. C. (1986). Tax compliance research: findings, problems, and prospects. Journal of Accounting Literature.

James, S., Wallschutzky, I. G., \& Sawyer, A. (1998). The complexities of tax simplification: Progress in Australia, New Zealand and the United Kingdom. Australian Tax Forum, 14(1), 29-68.

Kementerian Koperasi dan Usaha Kecil Menengah RI. (2012). Perkembangan data UMKM dan Usaha Besar tahun 2011-2012. Diakses 31 Mei 2013 dari http://www.depkop.go.id/phocadownload/data_umkm/sandingan_data_umkm_2011-2012.pdf

Kirchler, E. (2007). The Economic Psychology of Tax Behavior. UK: Cambridge University Press.

OECD. (2009). Taxation of SMEs. OECD Publishing. http://www.keepeek.com/Digital-AssetManagement/oecd/taxation/taxation-of-smes_9789264024748-en\#page1 
Pope, J. (1993b). The compliance costs of taxation in Australia and tax simplification: the issues. Australian Journal of $\quad$ Management, $18(1), \quad$ http://citeseerx.ist.psu.edu/viewdoc/download?doi=10.1.1.197.2791\&rep=rep1\&type=pdf

Pope, J., \& Abdul-Jabbar, H. (2008). Tax Compliance Cost of Small and Medium Enterprises in Malaysia: Policy Implications. Malaysia: Curtin University of Technology. http://espace.library.curtin.edu.au/webclient/StreamGate?folder_id=0\&dvs=1400053017780 4 96\&usePid1=true\&usePid2=true

Purnomo, H. (2011). 52 Juta UMK di Indonesia. Diakses 23 Agustus 2012 dari http://finance.detik.com

Republik Indonesia, Keputusan Direktur Jenderal Pajak Nomor 536/PJ./2000, Tentang Norma Penghitungan Penghasilan Neto Bagi Wajib Pajak yang dapat menghitung Penghasilan Neto dengan menggunakan Norma Penghitungan.

Republik Indonesia, Peraturan Direktur Jenderal Pajak Nomor 32/PJ/2010, Tentang Pelaksanaan Pengenaan Pajak Penghasilan Pasal 25 bagi Wajib Pajak Orang Pribadi Pengusaha Tertentu.

Republik Indonesia, Peraturan Menteri Keuangan Nomor 208/PMK.03/2009 Tentang Penghitungan Besarnya Angsuran Pajak Penghasilan dalam Tahun Pajak Berjalan yang harus Dibayar Sendiri oleh Wajib Pajak Baru, Bank, Sewa Guna Usaha dengan Hak Opsi, Badan Usaha Milik Negara, Badan Usaha Milik Daerah, Wajib Pajak Masuk Bursa dan Wajib Pajak lainnya yang Berdasarkan Ketentuan diharuskan membuat Laporan Keuangan Berkala termasuk Wajib Pajak Orang Pribadi Pengusaha Tertentu.

Republik Indonesia, Peraturan Menteri Keuangan Nomor 68/PMK.03/2010 Tentang Batasan Pengusaha Kecil Pajak Pertambahan Nilai

Republik Indonesia, Undang-Undang nomor 20 Tahun 2008 tentang Usaha Mikro Kecil dan Menengah.

Republik Indonesia, Undang-Undang Nomor 28 Tahun 2007 tentang Ketentuan Umum dan Tatacara Perpajakan.

Republik Indonesia, Undang-Undang Nomor 36 Tahun 2008, tentang Pajak Penghasilan.

Republik Indonesia, Undang-undang nomor 42 tahun 2009, Tentang Pajak Pertambahan Nilai barang dan jasa dan Pajak Penjualan atas Barang Mewah.

Sandford, C., Godwin, M. \& Hardwick, P. (1989). Administrative and Compliance Costs of Taxation. Fiscal Publication.

Sari, W. K. (2012). Tinjauan Kebijakan Norma Penghitungan Penghasilan Neto Berdasarkan Asas Kemudahan Administrasi dan Asas Keadilan. Tesis. UI.

Slemrod, J. (1992). Did the Tax Reform Act of 1986 simplify tax matters? Journal of Economic Perspectives, 6(1), 45-57.

Song, Y. D., \& Yarbrough, T. E. (1978). Tax ethics and taxpayer attitudes: a survey. Public Administration Review, 38(5), 442-452. 